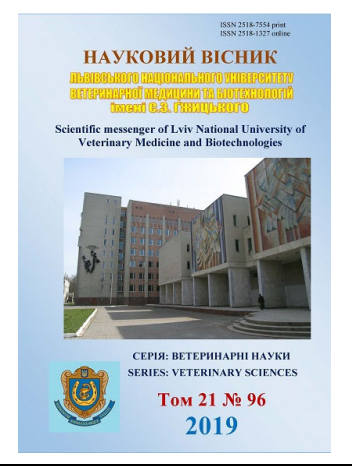

\author{
Науковий вісник Яьвівського національного університету \\ ветеринарної медицини та біотехнологій імені С.3. Гжицького. \\ Серія: Ветеринарні науки
}

\author{
Scientific Messenger of Lviv National University \\ of Veterinary Medicine and Biotechnologies. \\ Series: Veterinary sciences
}

UDC 619. 477

\title{
Medical treatment of animals in slavs in the middle ages
}

\author{
V. Prysyazhnyuk
}

Stepan Gzhytskyi National University of Veterinary Medicine and Biotechnologies Lviv, Ukraine

Article info

Received 07.10.2019

Received in revised form 06.11 .2019

Accepted 07.11.2019

Stepan Gzhytskyi National University of Veterinary Medicine and Biotechnologies Lviv, Pekarska Str., 50, Lviv, 79010, Ukraine. Tel.: +38-097-624-42-08 E-mail: Vasyl. prysyaznyuk@gmail.com
Prysyazhnyuk, V. (2019). Medical treatment of animals in slavs in the middle ages. Scientific Messenger of Lviv National University of Veterinary Medicine and Biotechnologies. Series: Veterinary sciences, 21(96), 71-74. doi: 10.32718/nvlvet9612

How the treatment of animals in Galicia evolved before the first printed veterinary works appeared today is little known to tell. The reason for this is the lack of relevant historical research in this area. However, this gap will no doubt be widened over time. This work is long and exhausting, since it is based on archival research and also on literature, which refers to a specific period. These will be pieces from different spheres of life, which, after proper segregation, will make it possible to complete this chapter. The above mentioned text of the treatment of horses by Slavs since 1394 is the oldest known mention of an equine doctor, as well as the salary for surgery and payment for medication. Confirming that in medieval Galicia, both the forging and the treatment of horses belonged to the blacksmith's duties. Preparation of medicines for horses was carried out by those who treated them. The blacksmiths, who were treated, began to be called Konoval. The oldest mention is recorded on parchment in 1505, also there is a guild sign of people of this profession. This is also evidenced by the engraving, whose origins date back to the Middle Ages. Blacksmiths are in the first place in the Middle Ages like equestrian doctors, they are already mentioned in the literature from the XI century. The grooms appear near the blacksmiths, but the name of the groom began dating only in the early 13th century. Since then, there are the first written mentions of poultry, falconers and dog-keepers. They were responsible for the care and treatment of the poultries or animals that had been cared for. In addition to agricultural content, there were also guidelines for the treatment and breeding of pets. In very few cases, veterinary writers describe the signs or causes of diseases, mainly by continuing to give the name of the disease and method of treatment. Therefore, treatment is empirical in the full sense of the word. Following the custom at the time of treatment, describe the treatment of each disease, as it is today in surgery, that is, starting from the head and ending at the feet. When the doctor could not make the correct diagnosis, he called the horse sick and recommended to treat it with a mixture consisting of butter, eggs and salt. By the term "attack" the author understood the signs of a very acute and usually fatal illness. Since drugs that deserve attention, we recommend sulfur, copper greens, turpentine, mustard, quicklime, mercury, tar, used as an ointment or liniment for external treatment. In addition to the aforementioned measures, the burning of the ferrous iron of the tumors was applied and then sprinkled with green copper, indicating the treatment of cutaneous form of sap. Medicines can be divided into three groups, namely: Medicinal products of vegetable, animal and mineral origin. The medicines were mixed and prepared mainly by the horse doctor, the medicines consisted mainly of home remedies and were readily available to anyone. In the liquid form were infused into the mouth, nose, enemas, ablution, bathing. Water, wine, vinegar and olive oil are the basis for liquid medicines. Ointments, suppositories, patches, pastes and poultices were used in the condensed form, Ointments are often used in a warm state. The basis for this was fats and wax. In the form of powdered substances that have blown into the eye or wounds. In addition to the above remedies, medicinal products and magical procedures were used for therapeutic purposes: words with superstitious signs related to religious worship were used to achieve treatment. Dressings and surgical instruments. A horn was served to deliver the medication, with certain preparations filled in the horn. Wounds were washed using a copper syringe. A leather bag made of the same material has replaced today's pourer. A hoof knife, a blood dispenser, a razor to remove hair are also mentioned, and also iron for burning ulcers and eczema. The dressing material is hemp yarn, scarves, mostly blue, spartan shale.

Key words: blacksmiths, horses, horse doctor, medical business, animals, folk medicine, diseases, medicines, instruments. 


\title{
Лікувальна справа тварин у слов'ян в середні віки
}

\author{
В.Я. Присяжнюк
}

Львівський національний університет ветеринарної медицини та біотехнологій імені С.3. Гюицького, м. Львів, Україна

Як розвивалося лікування тварин в Галичині до появи перших друкованих праць з ветеринарії, на сьогодні мало відомо. Причиною изього є відсутність відповідних історичних досліджень в иъьому напрямку. Однак нема сумніву, шзо з часом ияього розриву не буде. Ця робота тривала і виснажлива, оскільки базується на архівних дослідженнях та на літературі, яка належить до певного періоду. Це будуть частки з різних сфер життя, які лише після належної сегрегацї дозволять доповнити ию главу. Наведений вище текст про лікування коней слов'янами з 1394 року є найдавнішою відомою згадкою про кінного лікаря, а також про зарплату за операцію і оплату медикаментів. С підтвердження, щзо в середньовічній Галичині як кування, так і лікування коней належало до обов'язків коваля. Приготування ліків для коней здійснювалося тим, хто їх лікував. Ковалів, шо займалися лікуванням, почали називати коновалами. Найстаріма згадка записана на пергаменті в 1505 рочі, також там є гільдійний знак людей цієї професї. Про це також свідчить гравірування, походження якого сягає ще середніх віків. На периому місиі в середньовіччі є ковалі, як кінні лікарі вони вже згадуються в літературі з XI cm. Поряд з ковалями з являються конюхи, але назва конюхи виникла тільки на початку ХІІІ ст. 3 того часу є перші писемні згадки про птахівників, сокольників і собачників. До їхніх обов'язків входило догляд і лікування птахів або тварин, відданих їм на догляд. Крім сільськогосподарського змісту, також були вказівки щзодо лікування та розведення домашніх тварин. Автори ветеринарних праць дуже рідко описують ознаки хвороб або їх причини, в основному подають назву даної хвороби і спосіб лікування. Тому лікування є емпіричним у повному розумінні иьього слова. Дотримуючись звичаю в той час у прийнятому лікуванні, описують способи лікування кожного захворювання, так як ие сьогодні відбувається в хірургї, тобто починаючи від голови і закінчуючи ногами. Коли лікар не міг поставити правильний діагноз, називав коня хворим і рекомендував лікувати його сумішшю, шо складається з масла, яєць і солі. Під терміном “напад” автор розумів ознаки дуже гострої $i$ зазвичай смертельної хвороби. 3 препаратів, які заслуговують на увагу, рекомендували сірку, зелень міді, скипидар, гірчицю, негашене вапно, ртуть, дьоготь, які використовувалися у вигляді мазі або лініменту для зовнішнього лікування. На додаток до вищезазначених заходів застосовувалося припалювання розжареним залізом пухлин, а потім посипали зеленою міддю, щзо вказує на лікування шкірної форми сапу. Лікарські засоби можна поділити на три групи, а саме: лікарські засоби рослинного, тваринного $і$ мінерального походження. Ліки змішував і виготовляв переважно сам коновал, ліки складалися переважно з домашніх засобів $i$ були доступні кожному. У рідкому вигляді вливалися в рот, ніс, застосовували клізми, промивання, купання. Вода, вино, оцет $i$ оливкова олія - основа для рідких ліків. У згущеному вигляді використовували мазі, супозиторіі, пластирі, пасти і припарки. Мазі часто використовували в теплому стані. Основою для цуього були жири і віск. Ліки були у вигляді порошкоподібних речовин, які вдувалися в око або рани. Окрім вищезазначених засобів, для лікувальних иілей використовувалися лікарські засоби та магічні процедури: слова із забобонними ознаками, пов'язані з релігійними поклоніннями, було використано з метою лікування. Для подавання ліків служив ріг з певними препаратами. За допомогою мідного шприца промивалися рани. Шкіряний мішок з цього самого матеріалу заміняв сьогоднішній вливач. Крім того, згадуються копитовий ніж, пристрій для пускання крові, бритва для видалення волосся, а також залізо для припалювання виразок і екземи. Перев'язувальний матеріал - конопляна пряжа, хустки, переважно синього кольору, спартанські сланці.

Ключові слова: ковалі, коні, коновали, лікувальна справа, тварини, народна медицина, захворювання, лікарські засоби , інструменти.

\section{Вступ}

Впродовж останніх років опубліковано цілу низку наукових досліджень вітчизняних авторів (Kis, 1968; Bogojavlenskij, 1980; Verkhratskyi \& Zabludovskyi, 1991; Rudyk \& Bisiuk, 2000; Sadvari et al., 2000; Kurtiak \& Tkachuk, 2001; Verbytskyi et al., 2002; Prysiazhniuk, 2017), присвячених історії медицини, що розкривають питання зародження, становлення та розвитку лікувальної справи, в тому числі у різних регіонах України залежно від політичних і соціальноекономічних умов. У деяких наукових працях показано організацію і становлення державної ветеринарної служби певного краю, області (Rudyk \& Bisiuk, 2000; Verbytskyi et al., 2002) і України загалом. Мета дослідження: висвітлити питання діяльності фахівців лікувальної справи тварин у слов'ян в середні віки 3 метою зменшення захворювань та лікування тварин в певних історичних умовах в Галичині. Завдання дослідження полягали в тому, щоб отримати дані щодо організації форм роботи фахівців лікувальної справи тварин в середні віки в Україні, зокрема в Галичині, використання різноманітних лікувальних засобів при лікуванні тварин, розкрити сутність народної ветеринарії, діяльність народних цілителів 3 метою зменшення захворюваності тварин у певних політичних та соціально-економічних умовах.

\section{Матеріал і методи досліджень}

Матеріалом для вивчення лікувальної справи тварин на західноукраїнських землях в середні віки були окремі архівні документи Державного історичного архіву м. Львова, періодичні видання, статті, а також деякі вітчизняні та іноземні бібліографічні джерела Національної наукової бібліотеки імені В. Стефаника НАН України у м. Львові. При проведенні досліджень використано методи: хронологічний, системний, порівняльно-історичний, аналітичний.

\section{Результати та їх обговорення}

Як розвивалося лікування тварин в Галичині до появи перших друкованих праць з ветеринарії, сьогодні мало відомо. Причиною цього є відсутність відповідних історичних досліджень в цьому напрямку. 
Однак нема сумніву, що з часом цього розриву не буде. Ця робота тривала і виснажлива, оскільки базується на архівних дослідженнях та на літературі, яка належить до певного періоду. Це будуть частки 3 різних сфер життя, які лише після належної сегрегації дозволять доповнити цю главу.

Такою частиною $є$ витяг, наданий Чапським з бухгалтерських записів короля Владислава Ягайла, в якому написано: “Королі навіть довіряли металоконструкціям ковалів". 3 вихідних облікових записів короля Владислава Ягайла видно, що хворих коней залишали у ковалів. Наприклад, в 1394 році було видано гроші на потреби з догляду за залишеними кіньми короля у Вісліци в коваля Якуша для їхнього лікування. "Іншим на мило і за пускання крові королівському хворому коню ковалю заплачено гроші, а доглядальнику того коня Бартошу - дали на взуття 2 скойца. Пізніше за ліки для королівських коней, це для Біскупа і Валаха, заплачено ковалю 18 скойців, а Івану Венгринову - доглядачу коней на витрати на тиждень дали 6 скойців"

Наведений вище текст $є$ найдавнішою відомою згадкою про кінного лікаря, а також про зарплату за операцію і оплату медикаментів. Це підтвердження, що в середньовічній Польщі, до складу якої входила Галичина, як кування, так і лікування коней належало до обов'язків коваля. Приготування ліків для коней здійснювалося тим, хто їх лікував.

Ковалів, що займалися лікуванням, почали називати коновалами. Найстаріша згадка записана на пергаменті в 1505 році, також там $\epsilon$ гільдійний знак людей цієї професії. Про це також свідчить гравірування, походження якого сягає ще середніх віків.

Оригінал знизу має напис “ковалі-коновали”. Зображено коня перед кузнею з піднятою лівою ногою, щиколотка пов'язана 3 передпліччям. Мета задуму пов'язана 3 тим, щоб кінь не міг опустити ногу і був змушений стояти спокійно на 3-х ногах. Перед конем зображено конюха, який тримає в руці палку, яка слугована для ударів, дана йому ковалем. Коновал стоїть $з$ правої сторони коня і контролює кровотечу, яка сильним струменем стікає на землю. Це гравірування є найдавнішою відомою слов'янською ілюстрацією, а також свідченням лікувального втручання у ветеринарії. Над зображенням видно ковальські вироби і слюсарні знаки.

На першому місці в середньовіччі $є$ ковалі, як кінні лікарі вони вже згадуються в літературі з XI ст. Поряд 3 ковалями з'являються конюхи, але назва конюхи виникла тільки на початку XIII ст. 3 того часу є перші писемні згадки про птахівників, сокольників і собачників. До їхніх обов'язків входило догляд і лікування птахів або тварин, відданих їм на догляд. Крім сільськогосподарського змісту, також були вказівки щодо лікування та розведення домашніх тварин.

В останні століття середньовіччя італійці зайняли провідне місце в лікуванні тварин і ветеринарній літературі завдяки таким особам, як Йорданус Руффус, Петрус Кресентіус, Карло Руїні, Лоренцій Русий,
Убертус де Курттенова, Бартололло Грізон, Паскаль Каруціолло та багато інших.

Зокрема, високого рівня в Італії досягла література стосовно кінної науки і самого мистецтва кінного спорту. Після цього вони пройшли через багато століть, маючи сильний вплив на лікування тварин в європейських країнах, поки вчені-французи не перейняли від італійців першість на цю тему.

Переважний італійський вплив був уже в XV ст. в літературі про лікування тварин в Свропі і тривав без перерви аж до кінця XVIII ст.

Автори ветеринарних праць дуже рідко описують ознаки хвороб або їх причини, в основному продовжуючи таким чином, що подають назву даної хвороби i спосіб лікування. Тому лікування є емпіричним у повному розумінні цього слова. Дотримуючись звичаю у прийнятому в той час лікуванні, описують способи лікування кожного захворювання, так як це сьогодні відбувається в хірургії, тобто починаючи від голови і закінчуючи ногами. Лікування захворювань за принципами середньовічних ветеринарних фахівців було таким. Належить зазначити, що однією з найчастіших хірургічних процедур було пускання крові, і це 3 різних вен тіла коня. Застосовували не тільки при внутрішніх хворобах чи хірургічних, а також як засіб профілактики хвороб.

Лікування сапу, рекомендоване авторами, являє собою лікування, яке полягає в тампонуванні рани волокнами конопель, просочених козячим жиром, або вливання до носових порожнин ртуті, змішаної з оливковою олією.

3 набряком підщелепових лімфатичних вузлів пов'язано витоки (виділення) з носа. Лікарські засоби складаються 3 дієтичних процедур, таких як годування коня житом, приготовленим у воді, також оперативних - спроба відкрити набряк гарячим залізом, потім налити до рани розплавлену сірку, а набряк обгортати теплим хлібом з сіллю.

3 препаратів, які заслуговують на увагу, рекомендували сірку, зелень міді, каміння, скипидар (терпентин), гірчицю, негашене вапно, ртуть, дьоготь, які використовували у вигляді мазі або лініменту для зовнішнього лікування. На додаток до вищезазначених заходів застосовувалося припалювання розжареним залізом пухлин, а потім посипали зеленою міддю, що вказує на лікування шкірної форми сапу.

Лікарські засоби, використовувані в середні віки, можна поділити на три групи. Лікарські засоби рослинного походження: червона бабка, лавр, Боже дерево (листя або корінь), береза (листя), хрін, цибуля, часник, цитрусові, кориця, скабіоза польова, коров'як (корінь), дьоготь, винні дріжджі. Сливова губка, модрина, імбир, біла гірчиця, гіркота, гвоздика, білий імбир, омела, оленячі язики, ячмінь, просо, деревій, кмин, лопух (корінь), мох, медовик (корінь), мускат (квітка), мак. Олія кропу, льону, коноплі, маку, лавра. Оман (коріння), оцет, осика (кора), перець, кропива, пиво, мандрівник (корінь), конопля (пряжа), гречка, рута, смола, шафран, татарська трава, терпентин, 
вино, віск, грецькі горіхи, жито, смола 3 модрини, попіл, мед, оливкова олія.

Лікарські засоби тваринного походження: курячий білок, дощовий черв'як, обпалені ящірки, яйця птахів. Кров собаки, коня, крота, обпалені кості. Оленячий жир, жир вівці, кози. Кал людський, гусячий, свині, вівці, мило, людська сеча, молоко, масло, гусяче пір'я, блохи, бджоли, палені підошви взуття, бульйон. Іспанські мухи, хрущі травневі, жир собаки, перепілок, сало, смалець, шкаралупи з яєць. Воша, жовтки 3 яєць, жива жаба, козяча жовч.

Лікарські засоби мінерального походження: горілий галун, чорнило, терта глина, зелень міді, тертий ладан, купорос (залізний купорос), подрібнена сіль, порошкоподібне скло, холодна вода, негашене вапно, ртуть.

Ліки змішував і виготовляв переважно сам коваль, коновал. Ліки складалися здебільша 3 домашніх засобів і були доступні кожному. У рідкому вигляді вливалися в рот, ніс, застосовували клізми, промивання, купання. Вода, вино, оцет і оливкова олія - основа для рідких ліків.

У згущеному вигляді використовували мазі, супозиторії, пластирі, пасти і припарки. Мазі часто використовували в теплому стані. Основою для цього були жири і віск. Ліки були у вигляді порошкоподібних речовин, які вдувалися в око або рани.

Магічне лікування. Окрім вищезазначених засобів, для лікувальних цілей використовувалися лікарські засоби та магічні процедури: слова із забобонними ознаками, пов'язані з релігійними поклоніннями, було використано з метою лікування.

Для подавання ліків служив ріг з певними препаратами. За допомогою мідного шприца промивалися рани. Шкіряний мішок 3 цього ж матеріалу заміняв сьогоднішній вливач. Крім того, згадуються копитовий ніж, пристрій для пускання крові, бритва для видалення волосся, а також залізо для припалювання виразок і екземи. Перев'язувальний матеріал - конопляна пряжа, хустки, переважно синього кольору, спартанські сланці.

\section{Висновки}

1. Першими фахівцями лікувальної справи тварин у середні віки в Галичині були ковалі, коновали, конюхи, доглядачі птахів, собак, народні цілителі, знахарі, власники тварин.

2. Народна ветеринарна медицина розробила заходи, спрямовані на запобігання появі та поширенню заразних захворювань тварин і людей. Належить за- значити, що однією з найчастіших хірургічних процедур було пускання крові, і це 3 різних вен тіла коня, що застосовували не тільки при внутрішніх хворобах чи хірургічних, а також як засіб профілактики хвороб.

3. Для лікування тварин використовували засоби рослинного, тваринного і мінерального походження.

Перспективи подальших досліджень. Планується дослідити діяльність ветеринарних фахівців щодо організації санітарно-карантинних заходів та їхню роль в розвитку лікувальної справи і тваринництва в Галичині.

\section{References}

Aranchii, S.V. (1998). Istoriia veterynarnoi medytsyny Poltavshchyny. Poltava: Poltavskyi literator (in Ukrainian).

Bogojavlenskij, N.A. (1980). Drevnerusskoe vrachevanie v H1-HUIIst. M. (in Russian).

Kasova knyha tsekhu kovaliv. TsDIA m. Lvova. F. 52, O. 2, 996-999 (in Ukrainian).

Kis, Ya.P. (1968). Promyslovist Lvova u period feodalizmu. Lviv (in Ukrainian).

Knyha zapysiv protokoliv vyzvolennia tsekhu kovaliv. TsDIA m. Lvova. F. 52, O. 2, 989-995 (in Ukrainian).

Kodeks pryvileiv $\mathrm{i}$ prav $\mathrm{m}$. Lvova za 1356-1685rr. Ukladach Antonii Alembek. TsDIA m. Lvova. F. 52, O. 2, 1153 (in Ukrainian).

Kurtiak, B.M., \& Tkachuk, P.S. (2001). Narys istorii veterynarnoi medytsyny Lvivshchyny. Lviv: Triada plius (in Ukrainian).

Prysiazhniuk, V.Ia. (2017). Parostky likuvalnoi spravy tvaryn v Halychyni. Naukovyi visnyk LNUVMB im. S.Z. Hzhytskoho, 19(77), 158-161. doi: 10.15421/nvlvet7734 (in Ukrainian).

Rudyk, S.K., \& Bisiuk, I.Iu. (2000). Istoriia veterynarnoi medytsyny Kyivshchyny. K. Ahrosvit (in Ukrainian).

Sadvari, Yu.Iu., Bakhtyn, V.F., \& Dudash, A.V. (2000). Veterynarna medytsyna Zakarpattia na mezhi tysiacholit. Uzhhorod: Patent (in Ukrainian).

Tsentralnyi derzhavnyi istorychnyi arkhiv Ukrainy u $\mathrm{m}$. Lvovi (TsDIA), Fond 52,Opys 2, Sprava 8 (in Ukrainian).

Verbytskyi, P.I., Dostoievskyi, P.P., \& Rudyk, S.K. (2002). Istoriia veterynarnoi medytsyny Ukrainy. K. Vetinform (in Ukrainian).

Verkhratskyi, S.A., \& Zabludovskyi, P.Iu. (1991). Istoriia medytsyny. Kyiv (in Ukrainian).

Vytiahy z Lvivskykh zemskykh i miskykh aktiv u spravakh mista za 1411-1786 rr. TsDIA m. Lvova. F. 52, O. 2, 644 (in Ukrainian). 